\title{
HYDROLOGIC MONITORING PROGRAM IN ELDRIDGE-WILDE AND EAST LAKE ROAD WELL-FIELD AREAS, PINELLAS AND HILLSBOROUGH COUNTIES, FLORIDA, 1978
}

OPEN-FILE REPORT 80-1195

Prepared in cooperation with

PINELLAS COUNTY, FLORIDA

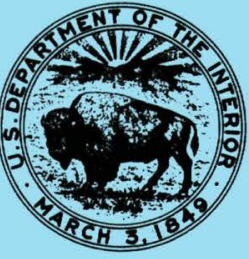




\section{CONVERSION FACTORS}

For readers who may prefer to use SI (metric) units rather than inch-pound units, conversion factors for terms used in this report are listed below:

Mu1tiply inch-pound unit

inch (in)

foot $(\mathrm{ft})$

mile (mi)

million gallons per day $(\mathrm{Mgal} / \mathrm{d})$

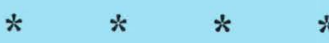

mean sea leve1 (ms1)
$\underline{B y}$

25.4

0.3048

1.609

0.0438

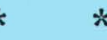

To obtain SI (metric) unit

millimeter (mm)

meter (m)

kilometer $(\mathrm{km})$

cubic meter per second $\left(\mathrm{m}^{3} / \mathrm{s}\right)$

National Geodetic Vertical Datum of 1929 (NGVD of 1929)

Abbreviations used

$\mathrm{mg} / \mathrm{L}=$ milligrams per liter 
UNITED STATES

DEPARTMENT OF THE INTERIOR

GEOLOGICAL SURVEY

HYDROLOGIC MONITORING PROGRAM IN ELDRIDGE-WILDE

AND EAST LAKE ROAD WELL-FIELD AREAS, PINELLAS

AND HILLSBOROUGH COUNTIES, FLORIDA, 1978

By Luther R. Mills

Open-File Report 80-1195

WITHDRAWN

SJRWMD

Library

Prepared in cooperation with

PINELLAS COUNTY, FLORIDA 


\section{UNITED STATES DEPARTMENT OF THE INTERIOR}

CECIL D. ANDRUS, Secretary

GEOLOGICAL SURVEY

H. William Menard, Director

For additional information write to:

U.S. Geological Survey

Water Resources Division

325 John Knox Road, Suite F-240

Tallahassee, Florida 32303 


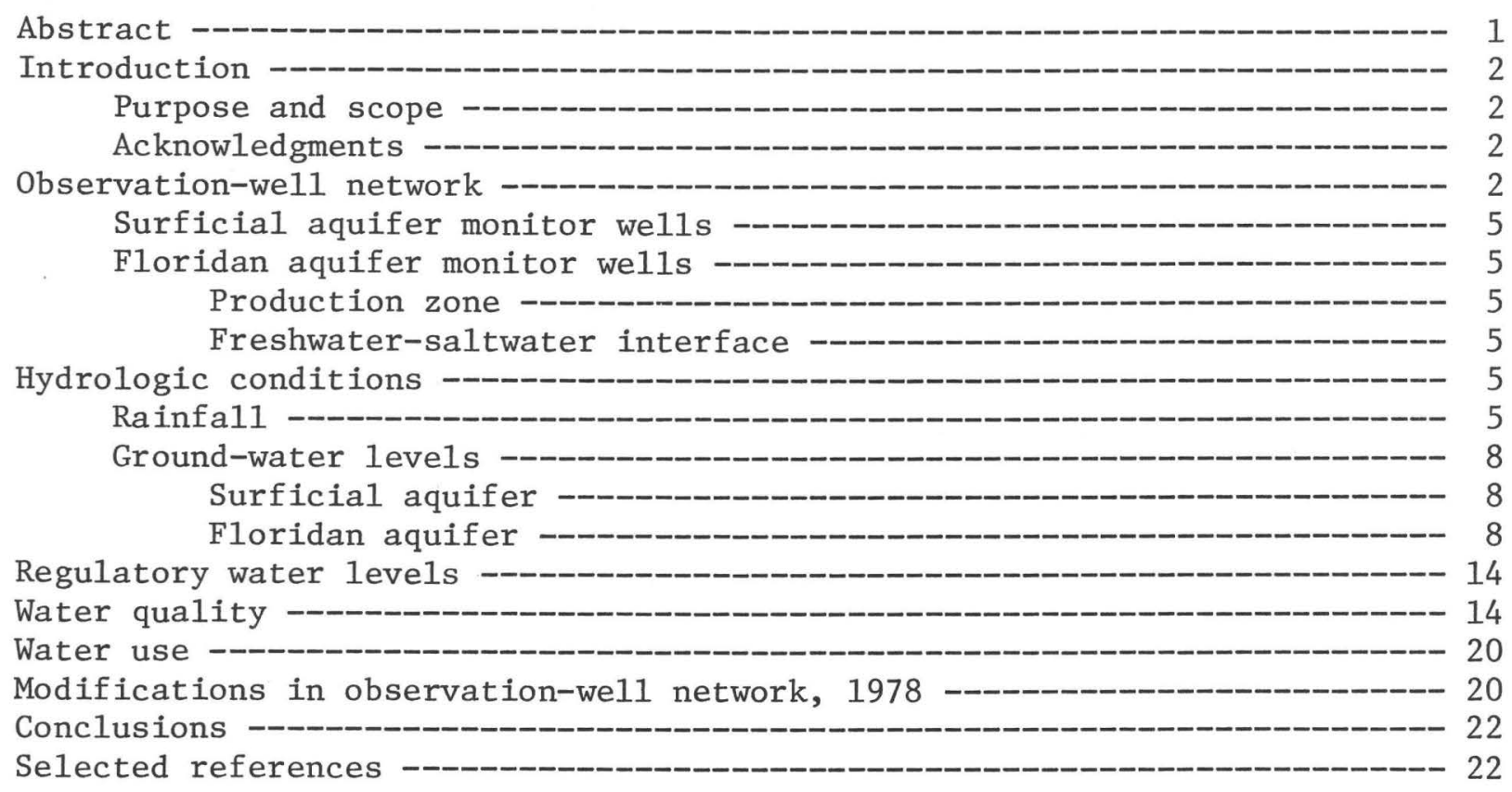

\section{ILLUSTRATIONS}

Figure 1. Map showing locations of observation wells in and near the Eldridge-Wilde and East Lake Road well fields --_--_-_-_---- 3

2. Generalized cross sections showing depths, casing depths, and open-hole intervals, where known, of observation wells in and near the Eldridge-Wilde and East Lake Road well fields - 4

3. Graph showing monthly rainfall at Eldridge-Wilde well field, 1974-78

4. Map showing water-level contours in the surficial aquifer,

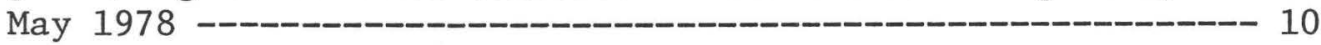

5. Map showing water-level contours in the surficial aquifer, September 1978 ------------ 11

6. Map showing potentiometric-surface contours in the Floridan aquifer, May 1978

7. Map showing potentiometric-surface contours in the Floridan aquifer, September 1978

8. Graph showing end-of-month maximum water levels in observation we11 2S deep, 1974-78

9. Graph showing end-of-month maximum water levels in observation we11 113A, 1974-78 -_-_-_-_-_-_-_-_-_-_-_-_------ 15 


\section{ILLUSTRATIONS - Continued}

Page

Figure 10. Graph showing end-of-month maximum water levels in observation well N-2, 1974-78

11. Graph showing end-of-month maximum water levels in observation we11 139G, 1974-78

12. Graph showing chloride concentrations in water from the North Lake Tarpon observation we11, 1974-78

13. Graph showing chloride concentrations in water from 730-foot depth in observation well S.W. deep, 1976-78

14. Section showing chloride concentrations at specific depths, September 1978

15. Graph showing monthly supply to Pinellas County Water System from Eldridge-Wilde, East Lake Road, and Cypress Creek well fields, 1974-78

TABLES

Page

Table 1. Data on observation wells that tap the surficial aquifer ----- 6

2. Data on observation wells that tap the production zone (F1oridan aquifer)

3. Data on observation wells that penetrate the freshwatersaltwater interface (Floridan aquifer)

4. Chloride concentrations in water from selected observation we11s 
HYDROLOGIC MONITORING PROGRAM IN ELDRIDGE-WILDE AND EAST LAKE ROAD
WELL-FIELD AREAS, PINELLAS AND HILLSBOROUGH COUNTIES, FLORIDA, 1978

By Luther R. Mills

ABSTRACT

Data obtained from the observation-we11 network in and adjacent to the Eldridge-Wilde and East Lake Road well fields during 1978, as well as rainfall and pumpage records, are presented and discussed. During 1978, the water table of the surficial aquifer and the potentiometric surface of the Floridan aquifer in the Eldridge-Wilde well field were near that of 1977 . Water levels fluctuate seasonally 4 to 6 feet in the Floridan aquifer, whereas those in the surficial aquifer fluctuate approximately 2 feet. In April 1978, water levels declined below regulatory limits set by the Southwest Florida Water Management District in regulatory we1ls $2 \mathrm{~S}, 113 \mathrm{~A}$, and $\mathrm{N}-2$, while those in we11 $139 \mathrm{G}$ remained above the limit.

Chloride limits have been established on five we11s at depth of the we11s and one well at three depths. Chloride exceeded regulatory limits in wells North Lake Tarpon and S.W. deep at the 730-foot depth; a11 other we1ls and depths showed little or no change in chloride trend. 


\section{INTRODUCTION}

The Eldridge-Wilde and East Lake Road well fields are located, respectively, northeast and east of Lake Tarpon in northeast Pinellas County (fig. 1). Part of the Eldridge-Wilde well field extends into the northwest part of Hillsborough County. The well fields, operated by Pinellas County, supply water to several municipalities and unincorporated areas of Pinellas County. A previous study of the area was made by Joyner and Gerhart (1980).

\section{Purpose and Scope}

The Southwest Florida Water Management District has established restrictions on withdrawal of water from the Eldridge-Wilde and East Lake Road well fields to prevent excessive lowering of water levels and deterioration of water quality by lateral or upward movement of saltwater. The purpose of this report is to present data from the observation-we11 network in and adjacent to the Eldridge-Wilde and East Lake Road well fields. Water-level and water-quality data obtained during 1978 are presented. Selected data from previous years are included to provide an indication of trends.

\section{Acknowledgments}

Appreciation is extended to A. O. Finney, Pinellas County Water System, for his cooperation in providing data and to the land owners who permitted access to their land and allowed the sampling of water and measuring of water levels in their wells.

\section{OBSERVATION-WELL NETWORK}

The observation-we11 network in the Eldridge-Wilde and East Lake Road well-field areas consists of 15 surficial aquifer wells (6 to 31 feet deep) and 38 Floridan aquifer wells (29 production-zone wells, 90 to 608 feet deep, and 9 saltwater-monitoring wells, 310 to 1,200 feet deep). In addition, the production wells in both fields are sampled monthly for chemical-quality analysis. The observation-well network is monitored by the Pinellas County Water System and the U.S. Geological Survey.

The observation wells at the Eldridge-Wilde and East Lake Road well fields are finished in either the surficial aquifer or the Floridan aquifer. Some wells, mostly those of greater depth, penetrate the freshwater-saltwater interface. Figure 1 shows locations of the observation wells. Figure 2 shows the depths, casing depths, and open-hole intervals (where known) of the we11s. 


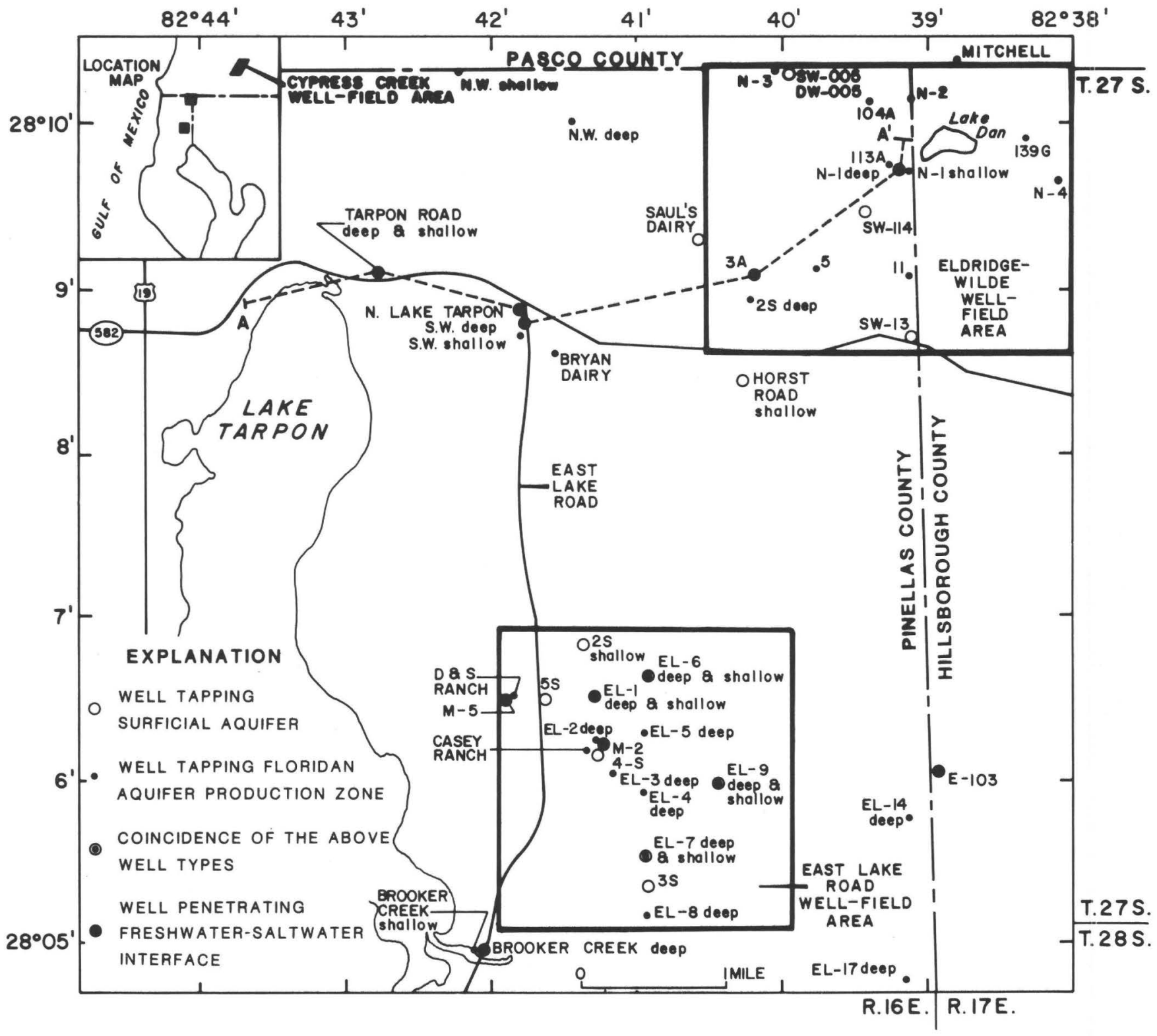

Figure 1.--Locations of observation wells in and near the Eldridge-Wilde and East Lake Road well fields. 
DEPTH OF WELL BELOW LAND SURFACE, IN FEET

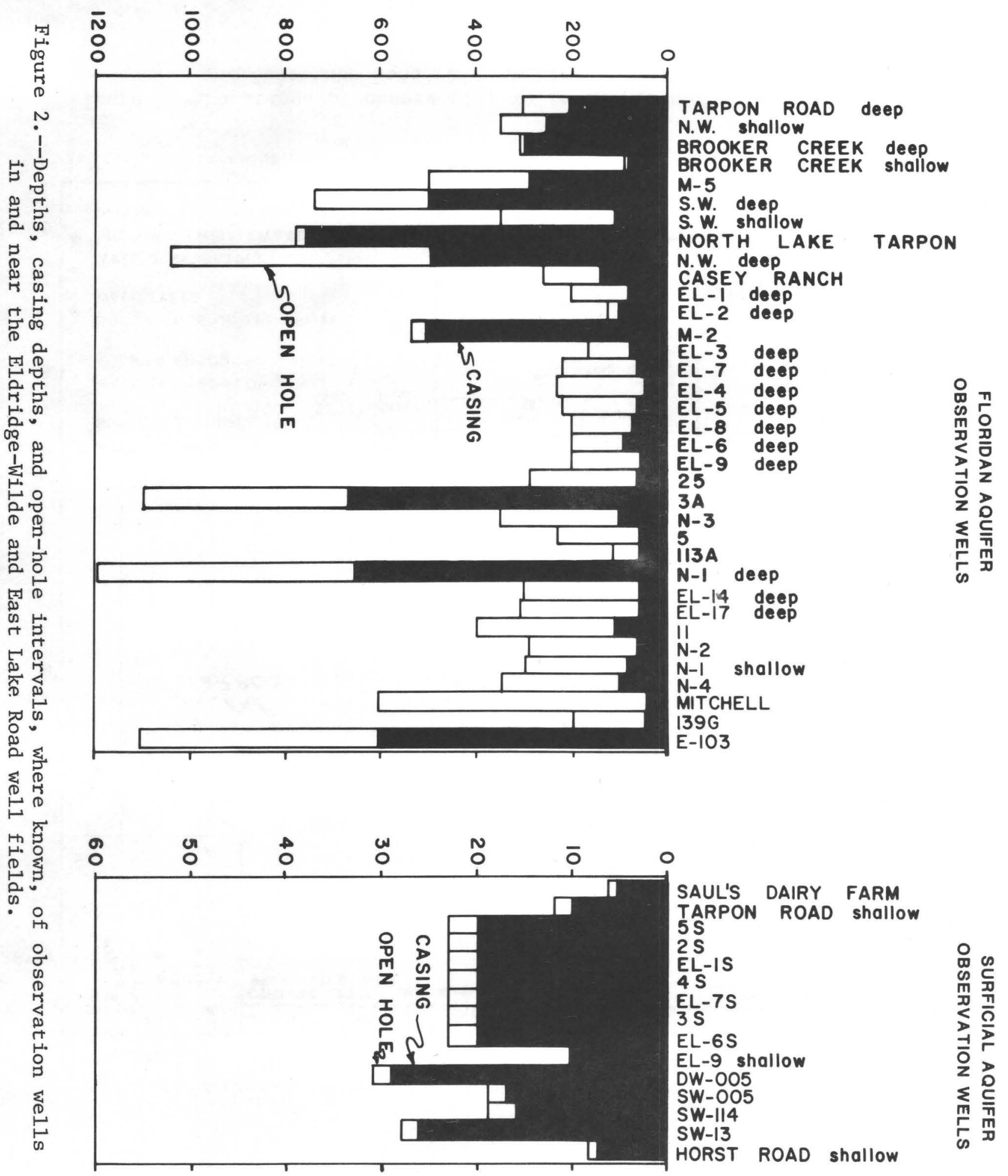




\section{Surficial Aquifer Monitor Wells}

The observation-we11 network includes 15 wells that tap the surficial aquifer (table 1). Of these wells, seven have been designated by the Southwest Florida Water Management District as regulatory wells. Regulatory wells are those constructed and monitored to insure minimum water levels and water-quality standards. As of 1978, regulatory levels had not been established for these wells. Water levels are measured weekly in well $4 \mathrm{~S}$ and monthly in the other six regulatory wells. Most of these regulatory wells are in the western and northwestern parts of East Lake Road well field (fig. 1) to monitor lateral movement of water between the well field and Lake Tarpon.

\section{Floridan Aquifer Monitor We11s}

\section{Production Zone}

Table 2 lists 29 observation wells that tap the production zones in the Eldridge-Wilde and East Lake Road well fields. Wells EL-1 deep through EL-8 deep are production as well as observation wells in East Lake Road well field. The others are used only for observation. The 58 production wells in the Eldridge-Wilde well field, not listed in the table, are sampled monthly for chemical analysis.

The wells 1isted in table 2 include 17 that have been designated regulatory wells by the Southwest Florida Water Management District. As of 1978, limits on water levels or water quality have been established on eight of these wells. Four wells have minimum water-level regulatory limits ranging from 4.0 to 16.0 feet above the National Geodetic Vertical Datum of 1929 (NGVD of 1929), and four have maximum chloride concentration limits ranging from 50 to 1,200 $\mathrm{mg} / \mathrm{L}$.

\section{Freshwater-Saltwater Interface}

Table 3 lists nine monitor wells, five of which have been designated as regulatory wells to monitor the freshwater-saltwater interface. As of 1978, maximum chloride concentration limits that range from 150 to $10,500 \mathrm{mg} / \mathrm{L}$ have been established on three of the wells. On one of these wells (S.W. deep)

limits have been established at three different depths, 560, 620, and 730 feet.

\section{HYDROLOGIC CONDITIONS}

\section{$\underline{\text { Rainfa11 }}$}

Several rain-gage stations are operated in the two well fields and adjacent areas. U.S. Weather Bureau records are available for Clearwater for 18 years; Tarpon Springs, 90 years; and Tampa, 88 years. The U.S. Geological 
Table 1.--Data on observation wells that tap the surficial aquifer

Monitoring agency: USGS, U.S. Geological Survey; PCWS, Pinellas County Water System. Frequency of data collection: b, bimonthly; m, monthly; w, weekly, Sr, stage-recorder.

\begin{tabular}{|c|c|c|c|c|c|c|c|c|}
\hline \multirow[b]{2}{*}{ We11 } & \multirow[b]{2}{*}{$\begin{array}{l}\text { Depth } \\
(\mathrm{ft})\end{array}$} & \multirow[b]{2}{*}{$\begin{array}{l}\text { Casing } \\
\text { depth } \\
\text { (ft) }\end{array}$} & \multirow[b]{2}{*}{$\begin{array}{l}\text { Dia- } \\
\text { meter } \\
\text { (in) }\end{array}$} & \multirow[b]{2}{*}{$\begin{array}{l}\text { Moni- } \\
\text { toring } \\
\text { agency }\end{array}$} & \multirow{2}{*}{$\begin{array}{c}\text { Fre- } \\
\text { quency } \\
\text { of } \\
\text { water- } \\
\text { leve1 } \\
\text { meas- } \\
\text { urement }\end{array}$} & \multicolumn{2}{|c|}{$\begin{array}{l}\text { Regulatory } \\
\text { limits }\end{array}$} & \multirow[b]{2}{*}{$\begin{array}{l}\text { Monitoring } \\
\text { purpose }\end{array}$} \\
\hline & & & & & & $\begin{array}{c}\text { Water } \\
\text { leve1 } \\
(\mathrm{ft} \\
\text { above } \\
\text { NGVD } \\
\text { of 1929) }\end{array}$ & $\begin{array}{l}\text { Ch1or- } \\
\text { ide } \\
\text { (mg/L) }\end{array}$ & \\
\hline Tarpon Road shallow & 12 & 10 & $1-1 / 4$ & USGS & $\mathrm{b}$ & None & None & Data \\
\hline $2 \mathrm{~S}$ & 23 & 20 & 2 & PCWS & $\mathrm{m}$ & None & None & Regulatory \\
\hline $\mathrm{EL}-6 \mathrm{~S}$ & 23 & 20 & 2 & PCWS & $\mathrm{m}$ & None & None & Regulatory \\
\hline EL-1S & 23 & 20 & 2 & PCWS & $\mathrm{m}$ & None & None & Regulatory \\
\hline $5 \mathrm{~S}$ & 23 & 20 & 2 & PCWS & $\mathrm{m}$ & None & None & Regulatory \\
\hline $4 \mathrm{~S}$ & 23 & 20 & 2 & PCWS & $w$ & None & None & Regulatory \\
\hline EL-7S & 23 & 20 & 2 & PCWS & $\mathrm{m}$ & None & None & Regulatory \\
\hline $3 \mathrm{~S}$ & 23 & 20 & 2 & PCWS & $\mathrm{m}$ & None & None & Regulatory \\
\hline Sauls Dairy Farm & 6 & 5 & $1-1 / 4$ & USGS & $\mathrm{m}$ & None & None & Data \\
\hline Horst Road shallow & 8 & 7 & $1-1 / 4$ & USGS & $\mathrm{m}$ & None & None & Data \\
\hline SW 005 & 19 & 17 & 2 & USGS & $\mathrm{m}$ & None & None & Data \\
\hline DW 005 & 31 & 29 & 2 & USGS & $\mathrm{m}$ & None & None & Data \\
\hline SW 13 & 28 & 26 & 2 & USGS & $\mathrm{m}$ & None & None & Data \\
\hline SW 114 & 19 & 16 & $1-1 / 4$ & USGS & $\mathrm{m}$ & None & None & Data \\
\hline EL-9 shallow & 10 & 8 & 4 & USGS & $\mathrm{Sr}$ & None & None & Data \\
\hline
\end{tabular}


Table 2.--Data on observation wells that tap the production zone (Floridan aquifer)

Monitoring agency: USGS, U.S. Geological Survey, PCWS, Pinellas County Water System.

Parameters monitored and frequency: Sm, stage-monthly; $\mathrm{Cb}$, chloride-bimonth1y; Sb, stage-bimonthly;

$\mathrm{C}$, chloride; $\mathrm{K}$, specific conductance; DS, dissolved solids; $\mathrm{SO}_{4}$, sulfate; m, monthly; Cm, chloride-monthly; $\mathrm{Sr}$, stage-recorder; ${ }^{4}$ Sw, stage-weekly.

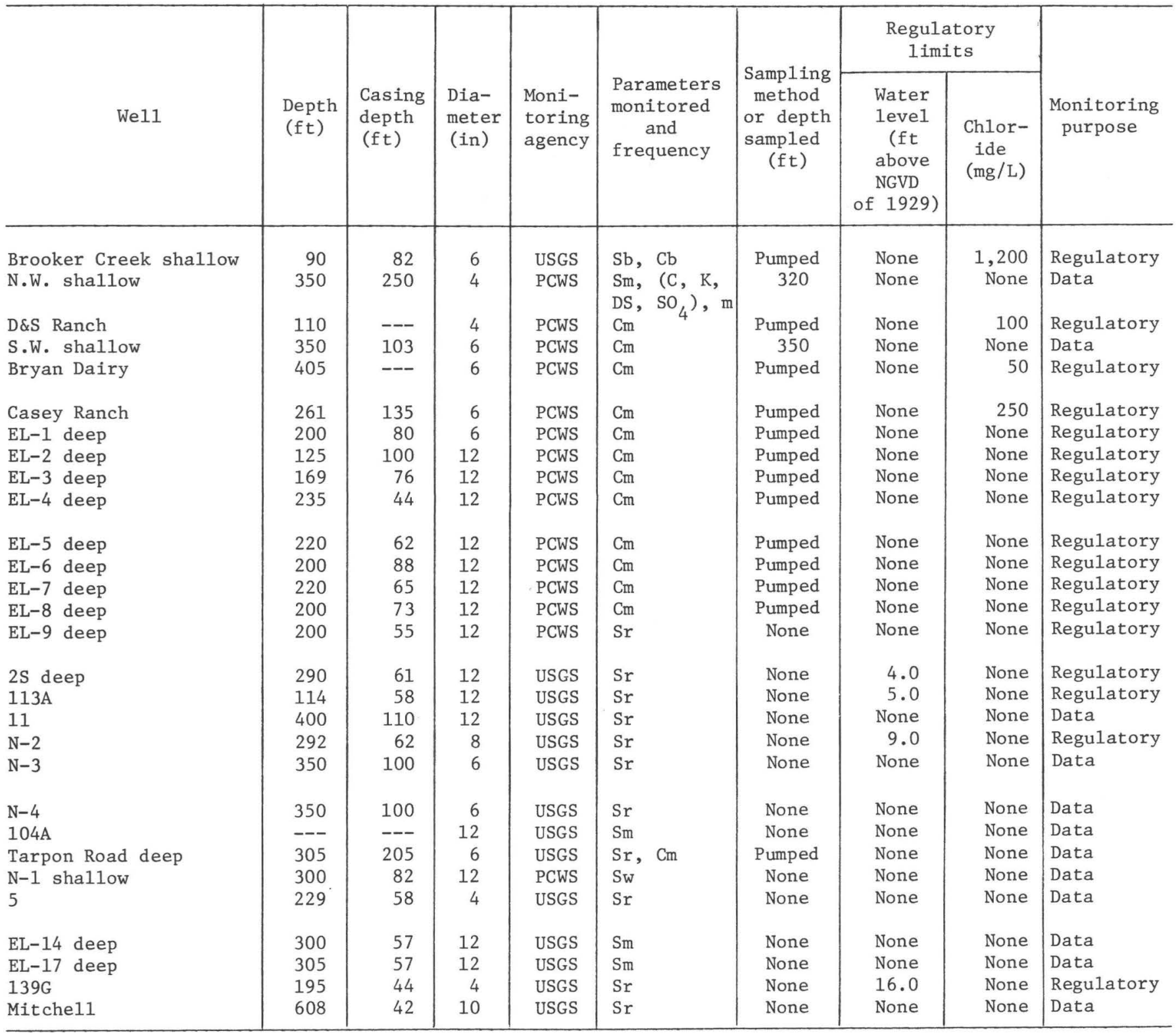


Survey has collected daily rainfall data from a recording station in the Eldridge-Wilde well field since April 1973. The monthly rainfall at this station for 5 years, 1974 through 1978, is shown in figure 3. At the well-field station, rainfall was 51.78 inches in 1978, which is equal to the average annual rainfall (52 inches for the period of record), and was also near normal when compared with the long-term average annual rainfall for the U.S. Weather Bureau stations at Clearwater (53.0 inches), Tarpon Springs (53.7 inches), and Tampa (49.4 inches).

\section{Ground-Water Levels}

The observation-well network is jointly operated by the Pinellas County Water System and the U.S. Geological Survey. The Pinellas County agency maintains two recorders--one in we11 EL-9 deep and the other in we11 E-103--for continuous measurement of the potentiometric surface of the Floridan aquifer. The county also measures water levels weekly or monthly in many of the surficial aquifer observation wells and production-zone observation wells. The U.S. Geological Survey maintains recorders on 12 wells for continuous measurement of water levels and also measures water levels monthly or bimonthly in other surficial aquifer and Floridan aquifer observation wells. In addition, mass water-level measurements of the well fields are made in May (when water levels are expected to be lowest) and in september (when water levels are expected to be highest). The mass measurements are used for the preparation of water-level contour maps released twice annually (Wolansky and others, 1978a and $1978 \mathrm{~b})$.

\section{Surficial Aquifer}

The water table fluctuates seasonally approximately 2 feet throughout most of the Eldridge-Wilde well field. However, there is a small area in the southcentral part of the well field, lying parallel and west of the HillsboroughPinellas County line, where water levels seasonally fluctuate approximately 4 feet. Figures 4 and 5 show water-table contours for the surficial aquifer in May and September 1978. Recovery of the water table from May to September ranged from 4 feet in the south-central part of the Eldridge-Wilde well field to 2 feet throughout the other parts. A water-level change of less than 1 foot occurred in the water table from May to September 1978 in the East Lake Road well-field area.

\section{Floridan aquifer}

The potentiometric surface of the Floridan aquifer in the Eldridge-Wilde and East Lake Road well fields in May and September 1978 is shown in figures 6 and 7. Pumpage from the Eldridge-Wilde well field caused a cone of depression exhibited in both the May and September maps. Water levels recovered 4 feet from the seasonal low in May to the seasonal high in September. 


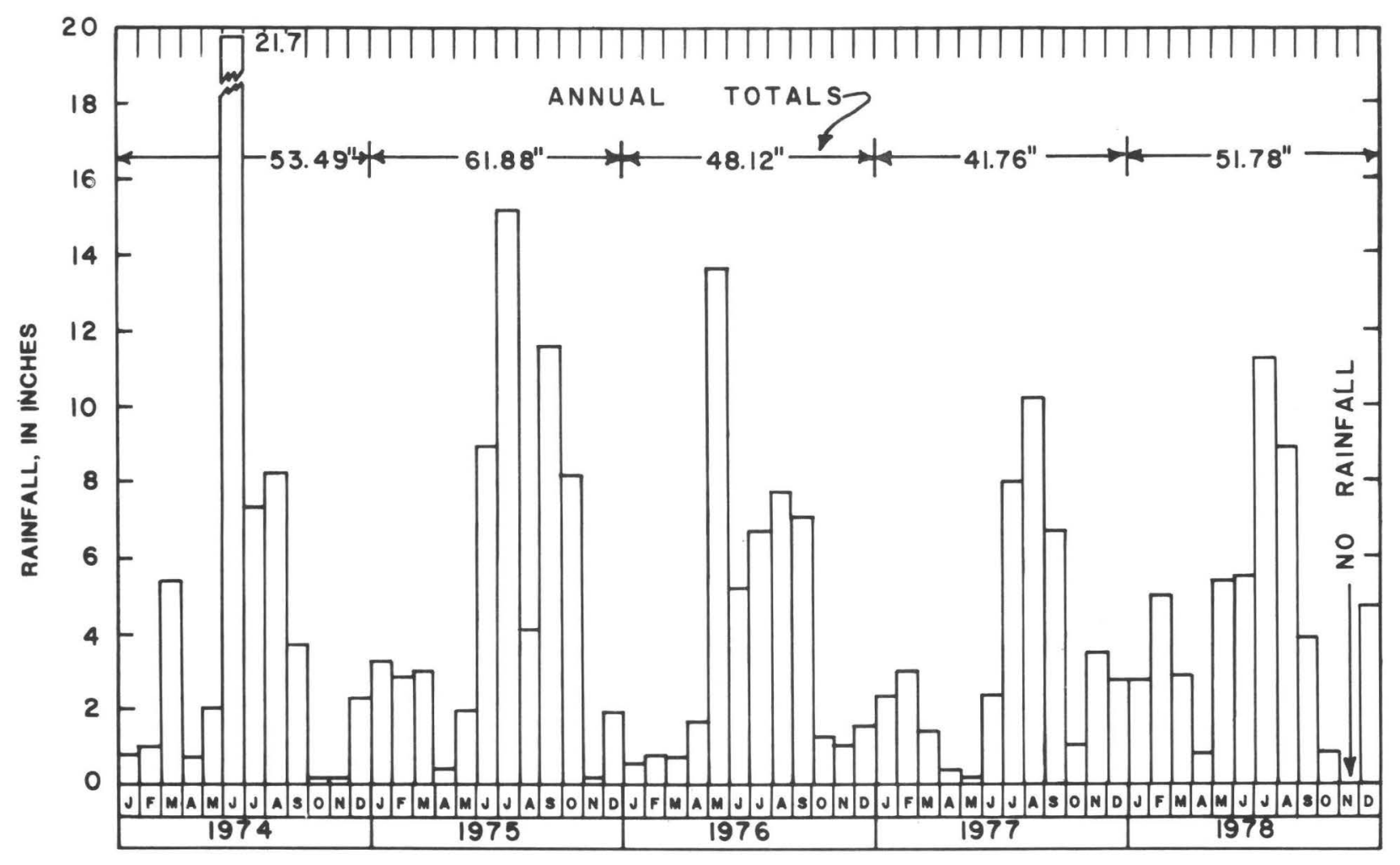

Figure 3.--Monthly rainfall at Eldridge-Wilde well field, 1974-78. 


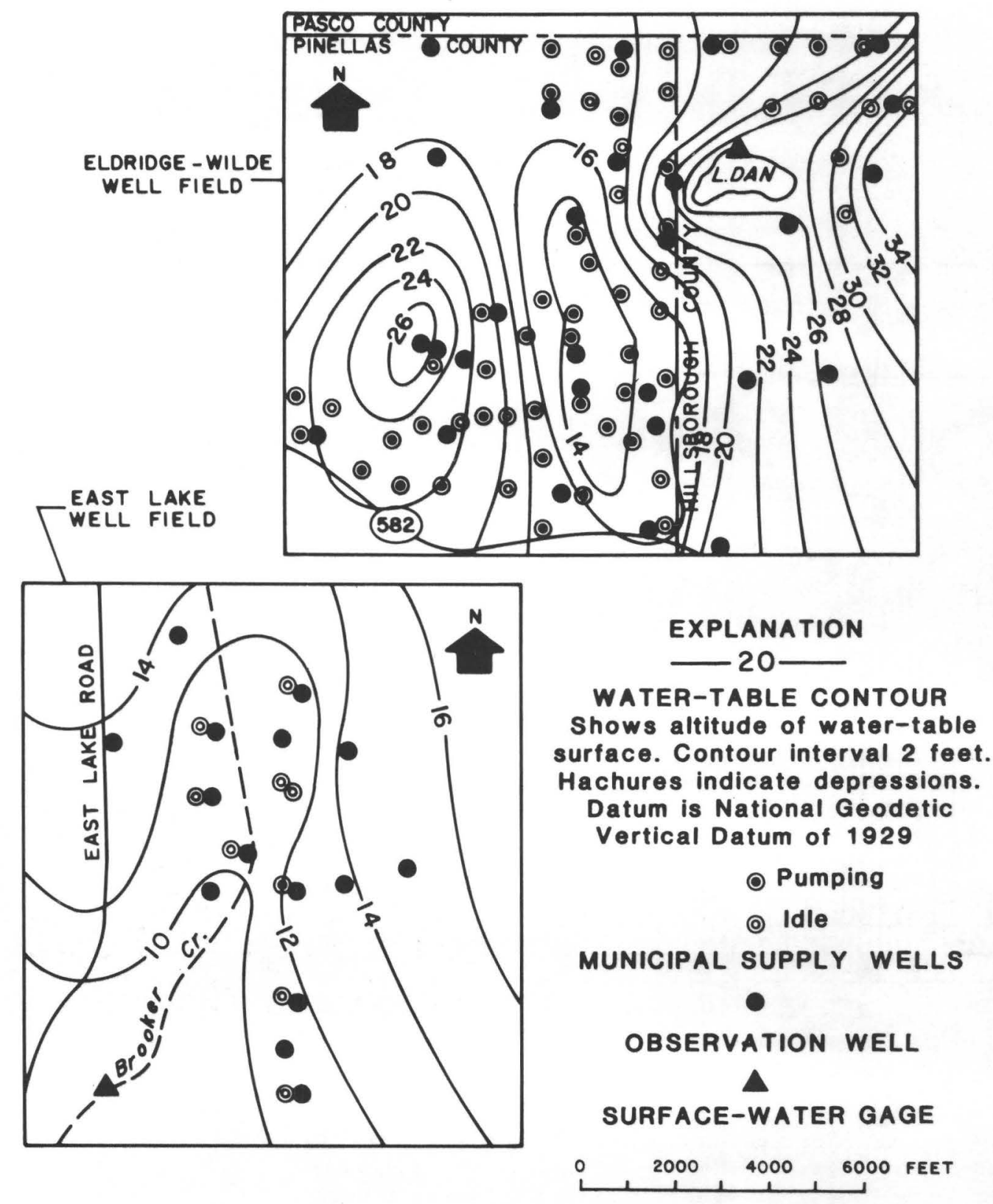

Figure 4.--Water-level contours in the surficial aquifer, May 1978 (from Wolansky, Mills, and Woodham, 1978a). 


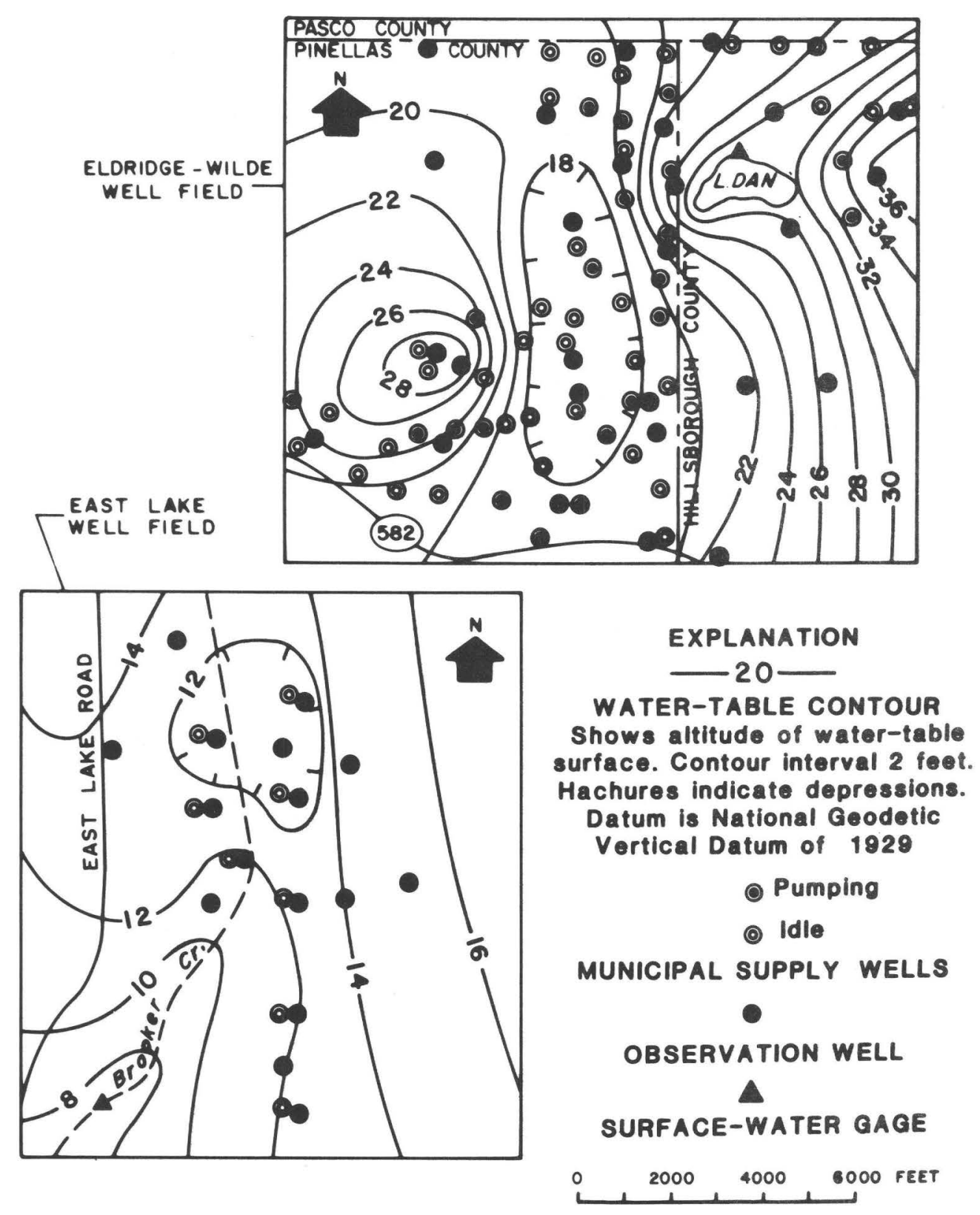

Figure 5.--Water-level contours in the surficial aquifer, September 1978 (from Wolansky, Mills, and Woodham, 1978b). 


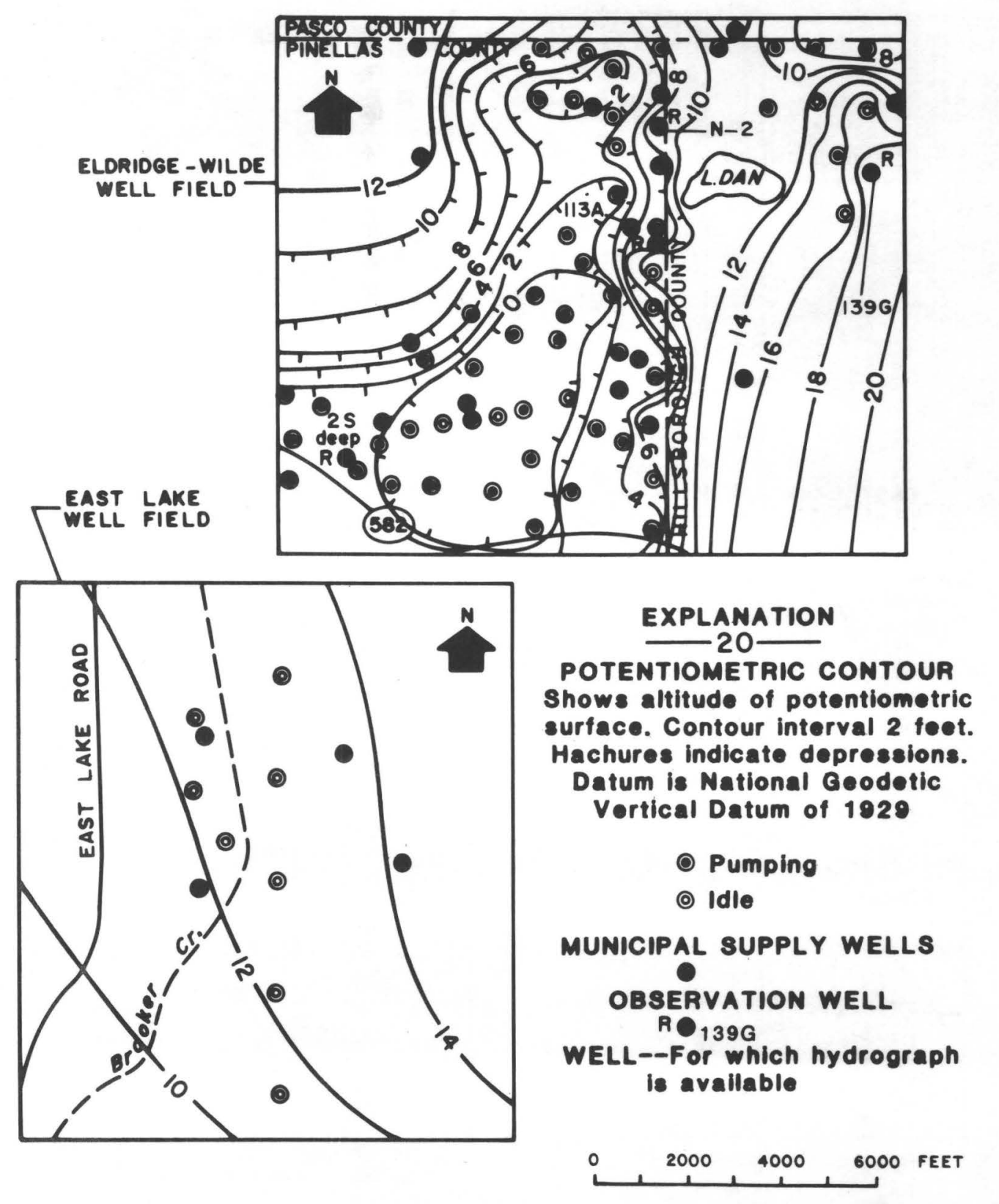

Figure 6.--Potentiometric-surface contours in the Floridan aquifer, May 1978 (from Wolansky, Mills, and Woodham, 1978a). 


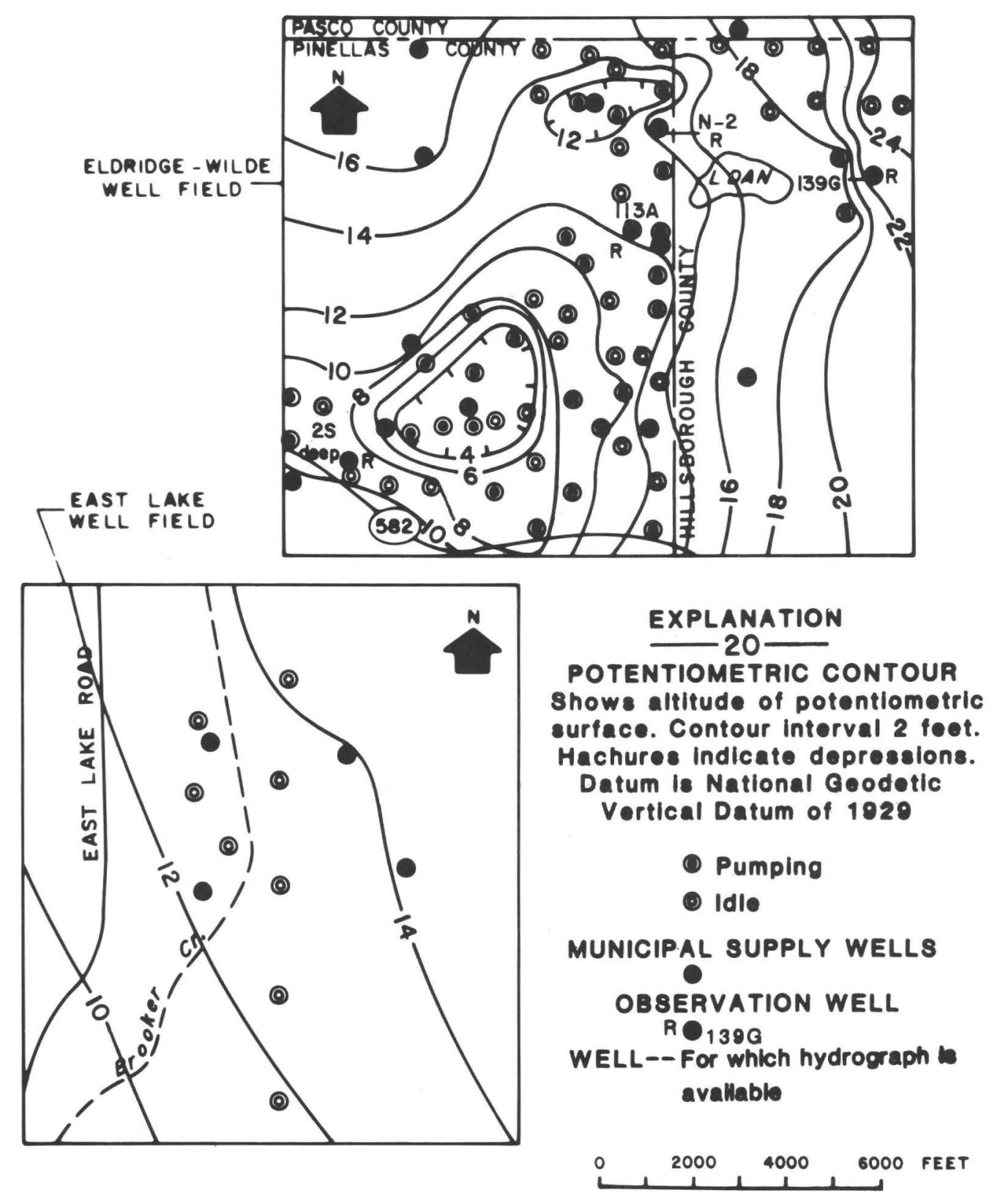

Figure 7.--Potentiometric-surface contours in the Floridan aquifer, September 1978 (from Wolansky, Mills, and Woodham, 1978b). 
The East Lake Road well-field pumpage was reduced during January through July and was discontinued in August through December 1978. The seasona1 waterlevel fluctuation in East Lake Road well field during 1978 was less than 1 foot.

\section{REGULATORY WATER LEVELS}

Figures 8-11 show the end-of-month maximum water-level elevations for 1974 through 1978 at the four regulatory wells in the Eldridge-Wilde well field. The regulatory limit established by the Southwest Florida Water Management District for each well is shown on the illustrations. A11 wells had water levels that declined below regulatory levels 4 years out of 5 . These minimum levels occurred during the seasonal low water-level period in the spring.

\section{WATER QUALITY}

Chloride concentrations determined in 1977 and 1978 for 12 observation wells are listed in table 4. Seven wells have maximum regulatory limits established for chloride concentrations, either in samples pumped from the wells or in samples obtained at a given depth in the well bore. In four wells, chloride concentrations are determined at more than one depth (table 3 ).

Two wells, North Lake Tarpon at depth and S.W. deep at the 730-foot sampling point, have exceeded regulatory limits in their chloride concentrations. Chloride concentrations remained above regulatory limits in the North Iake Tarpon we11 throughout 1978, whereas S.W. deep, at the 730-foot sampling point, exceeded the limit during June but was below the limit by September. Chloride concentrations in the remainder of the wells were about the same in 1978 as in 1977.

North Lake Tarpon well samples reached a maximum chloride concentration of about 13,000 mg/L in April and June of 1978 and then decreased to $12,000 \mathrm{mg} / \mathrm{L}$ in July and remained at that level until the end of the year (fig. 12). The $13,000 \mathrm{mg} / \mathrm{L}$ maximum concentration is $2,500 \mathrm{mg} / \mathrm{L}$ higher than the regulatory limit.

Fluctuations in chloride concentration in the S.W. deep well at 730 feet are shown in figure 13. The regulatory limit for chloride concentration in water from this leve1 is $6,000 \mathrm{mg} / \mathrm{L}$. In June 1978 , the concentration reached a maximum of $6,446 \mathrm{mg} / \mathrm{L}$. The maximum since sampling began at this well is $8,250 \mathrm{mg} / \mathrm{L}$ that occurred in January 1977 .

The chloride concentrations ranged from 12,000 to $13,000 \mathrm{mg} / \mathrm{L}$ from the sampled interval 758-780 feet in the North Lake Tarpon well and from 850 to $6,446 \mathrm{mg} / \mathrm{L}$ at the 730-foot depth of S.W. deep well during 1978. These two wells are about 600 feet apart. The wide range of the chloride concentrations in the S.W. deep well and the relatively narrow range in the North Lake Tarpon well have been explained by Joyner and Gerhart (1980) to be caused by the difference in the interval of the Floridan aquifer to which they are open. The North Lake Tarpon well is open to a zone that is about 30 feet deeper than the S.W. deep we11. According to Joyner and Gerhart (1980), the higher concentrations and lower variability of chloride in the North Lake Tarpon deep well 


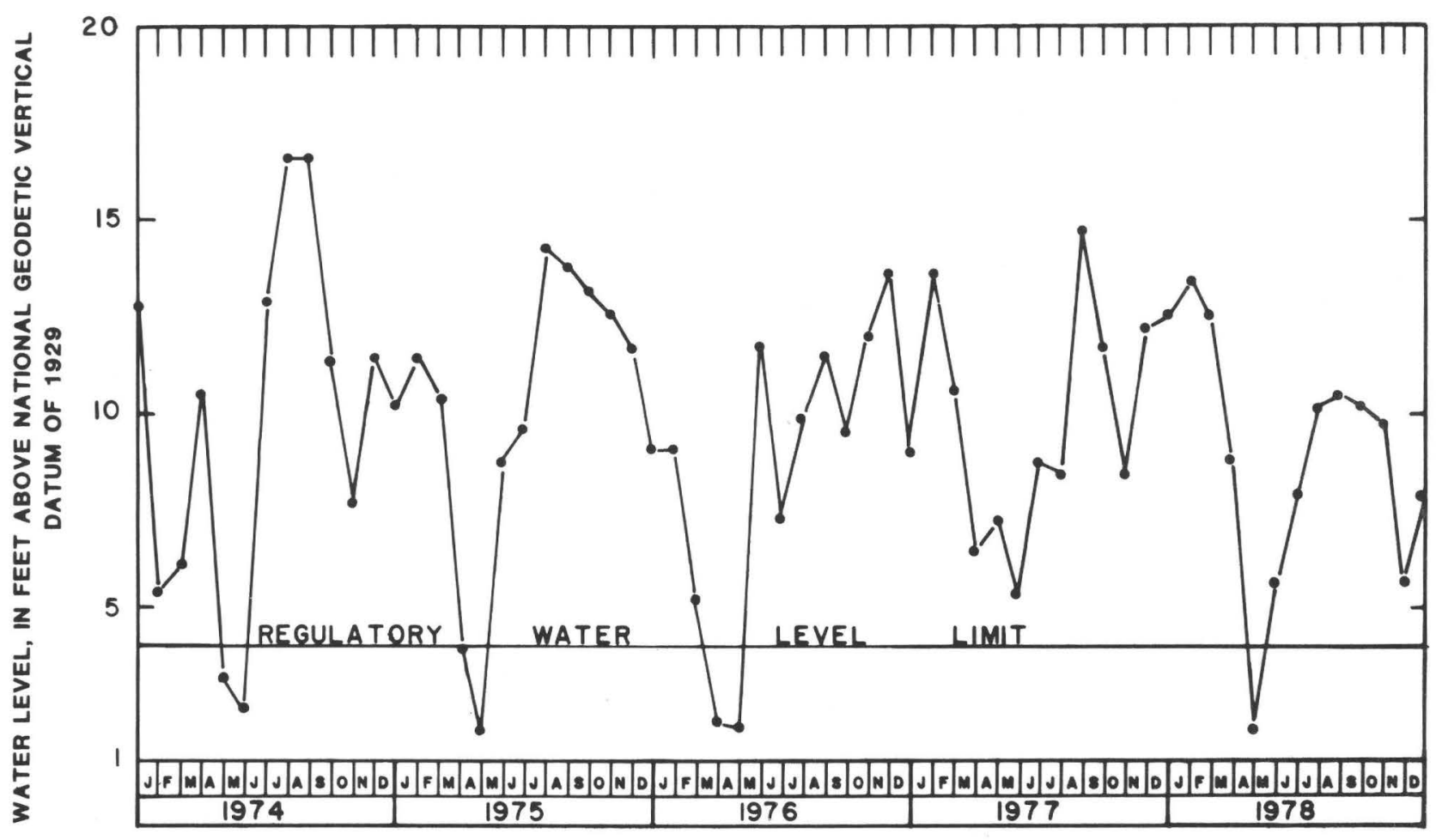

Figure 8.--End-of-month maximum water levels in observation well 2S deep, 1974-78.

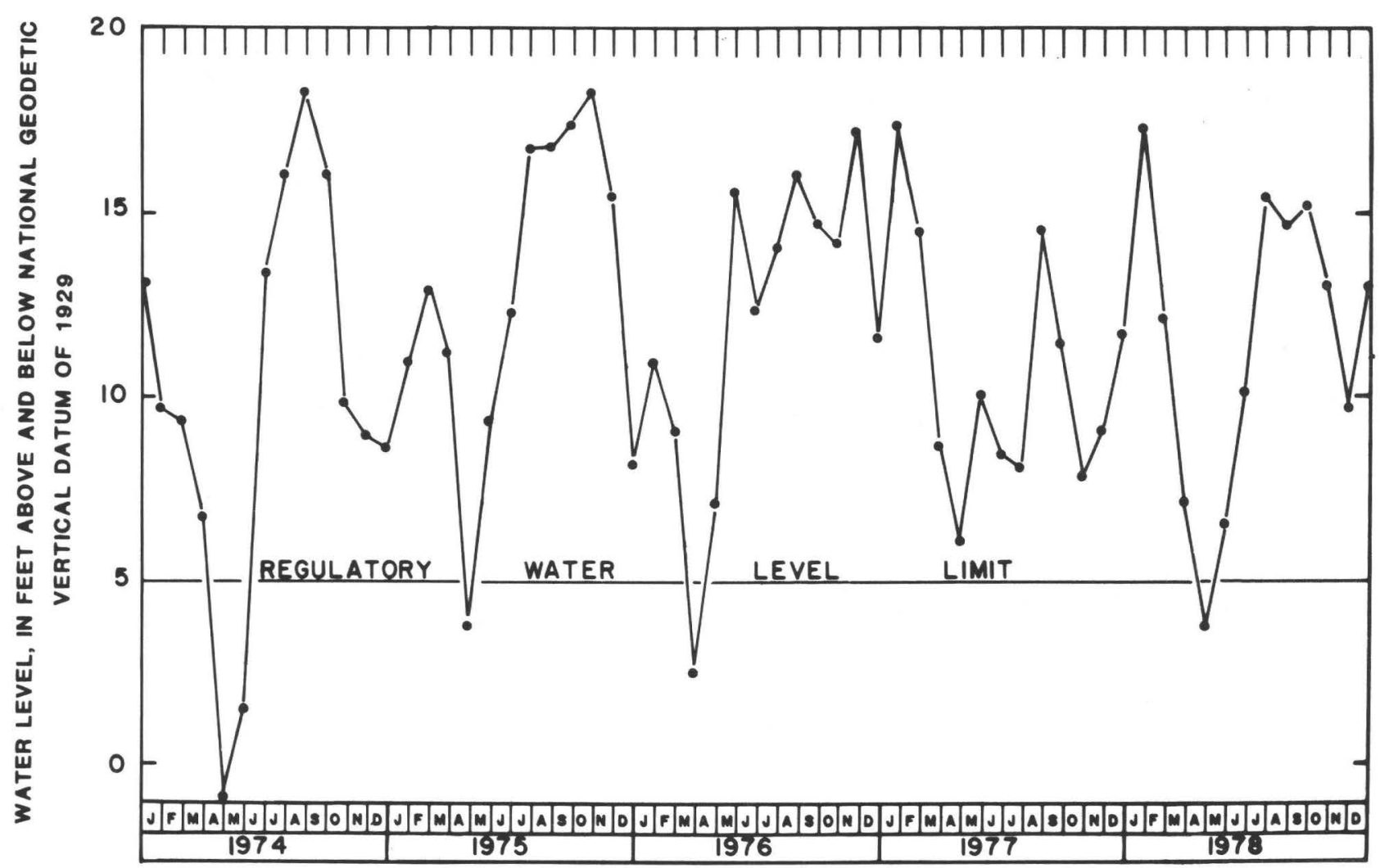

Figure 9.--End-of-month maximum water levels in observation we11 $113 \mathrm{~A}, 1974-78$. 


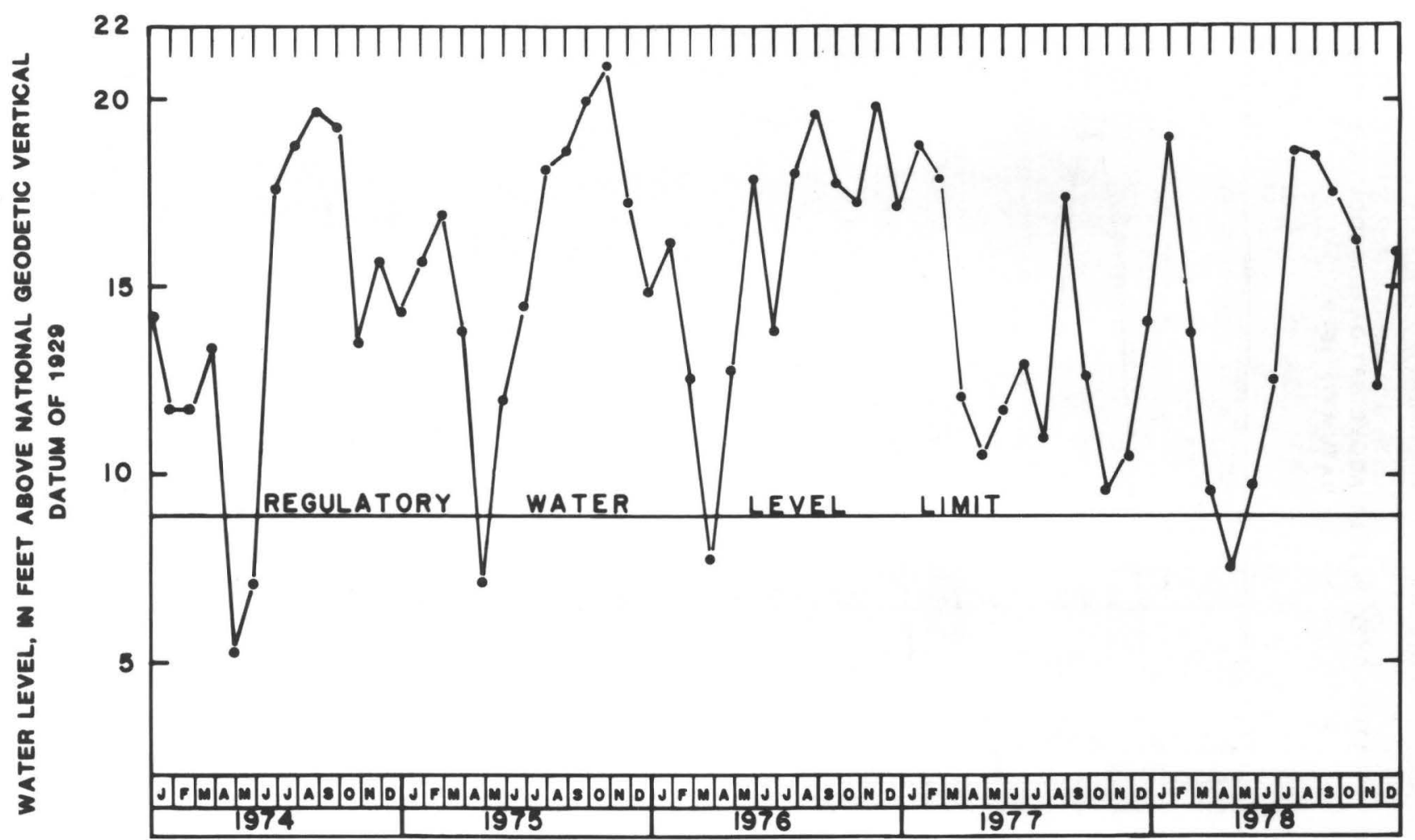

Figure 10.--End-of-month maximum water levels in observation wel1 $\mathrm{N}-2$, 1974-78.

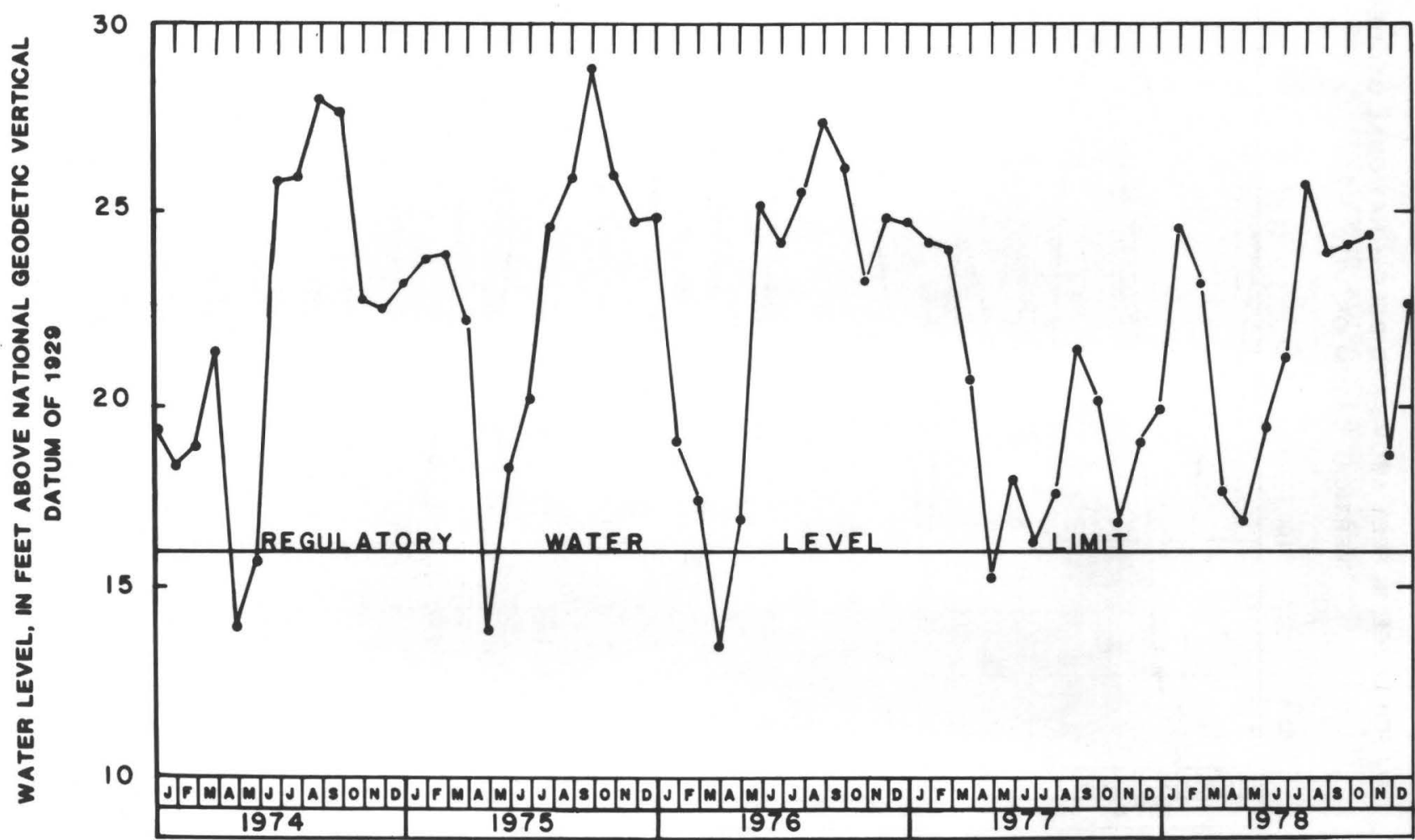

Figure 11.--End-of-month maximum water levels in observation we11 139G, 1974-78. 


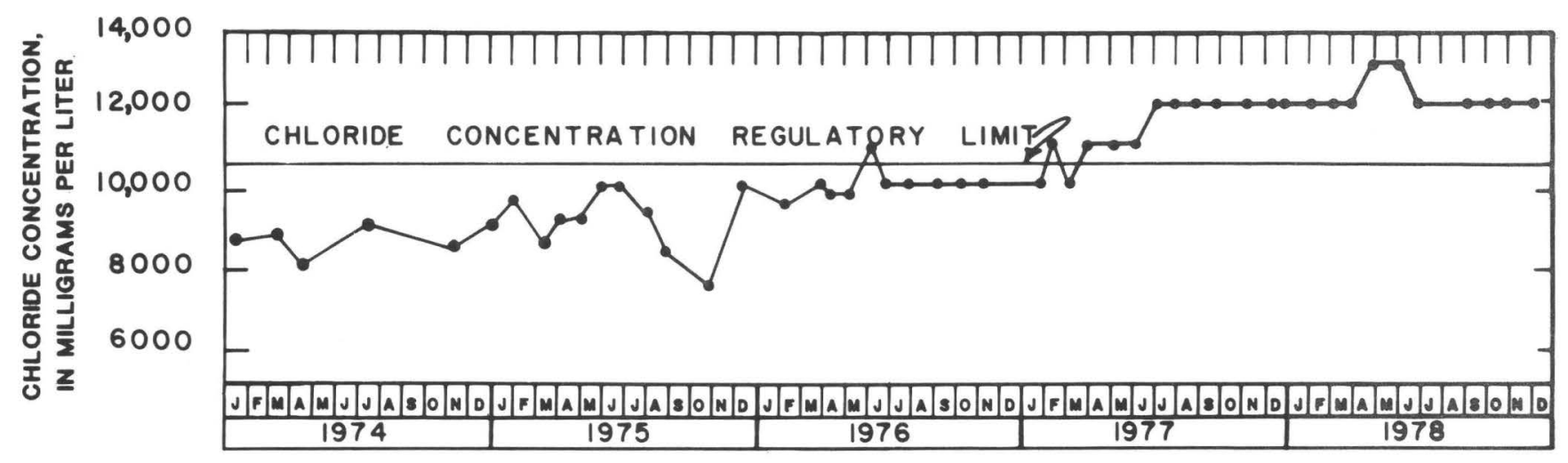

Figure 12.--Chloride concentrations in water from the North Lake Tarpon observation we11, 1974-78.

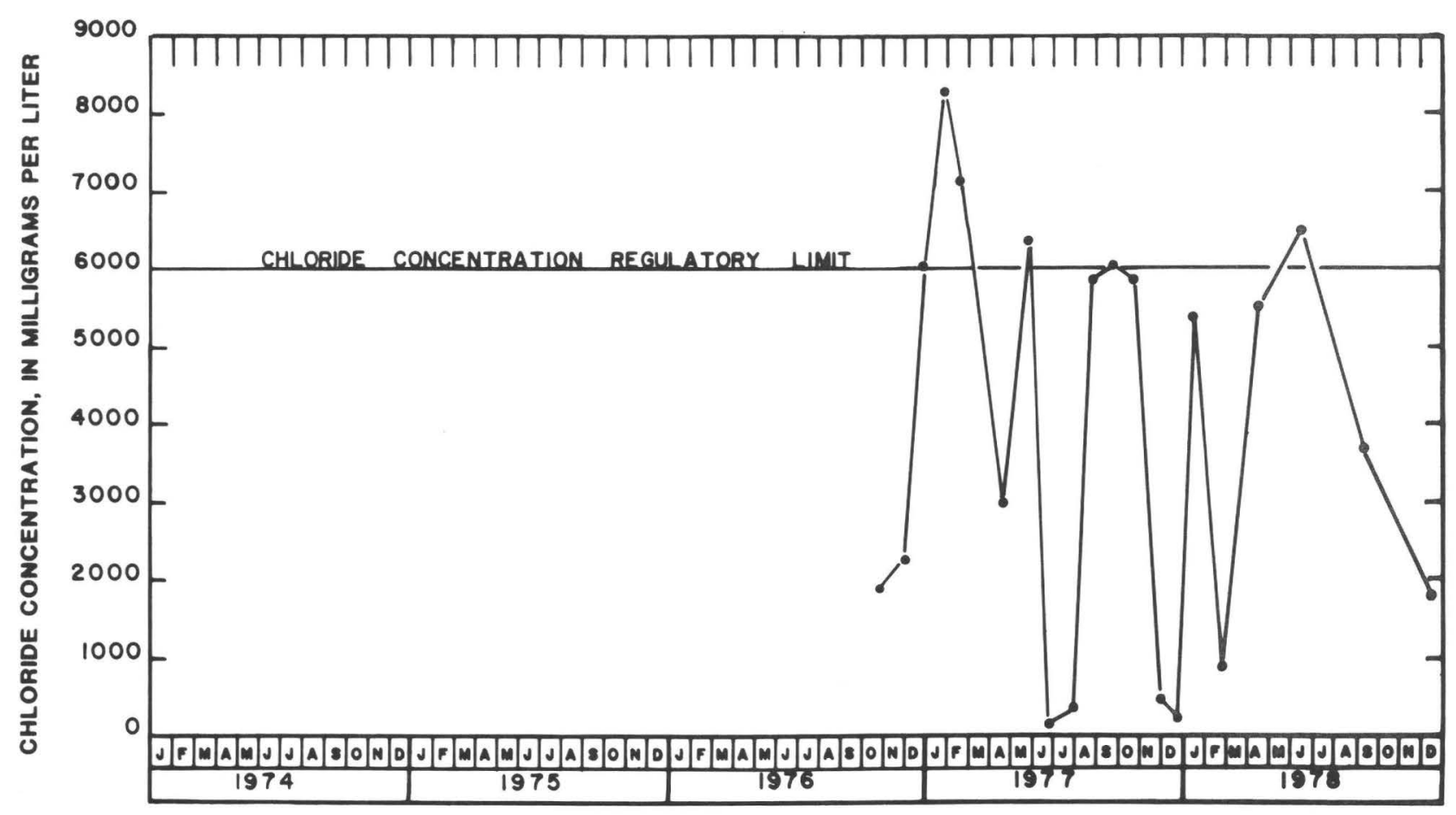

Figure 13.--Chloride concentrations in water from 730-foot depth in observation we11 S.W. deep, 1976-78. 
Table 3.--Data on observation wells that penetrate the freshwater-saltwater interface (Floridan aquifer)

Monitoring agency: USGS, U.S. Geologica1 Survey; PCWS, Pinellas County Water System.

Parameters monitored and frequency: Sr, stage-recorder; Cb, chloride-bimonthly; K, specific conductance;

DS, dissolved solids; C, chloride; So, sulfate; S, stage; a, annual; Sm, stage-monthly; Cm, chloride-monthly; sa, semiannual.

\begin{tabular}{|c|c|c|c|c|c|c|c|c|c|}
\hline We11 & $\begin{array}{l}\text { Depth } \\
(\mathrm{ft})\end{array}$ & $\begin{array}{l}\text { Casing } \\
\text { depth } \\
\text { (ft) }\end{array}$ & $\begin{array}{l}\text { Dia- } \\
\text { meter } \\
\text { (in) }\end{array}$ & $\begin{array}{l}\text { Moni- } \\
\text { toring } \\
\text { agency }\end{array}$ & $\begin{array}{l}\text { Parameters } \\
\text { monitored } \\
\text { and } \\
\text { frequency }\end{array}$ & $\begin{array}{l}\text { Sampling } \\
\text { method } \\
\text { or depth } \\
\text { sampled } \\
(\mathrm{ft})\end{array}$ & \multicolumn{2}{|c|}{$\begin{array}{c}\text { Regulatory } \\
\text { limits }\end{array}$} & $\begin{array}{l}\text { Monitoring } \\
\text { purpose }\end{array}$ \\
\hline Brooker Creek deep & 310 & 300 & 6 & USGS & $\mathrm{Sr}, \mathrm{Cb}$ & Pumped & None & 1,500 & Regulatory \\
\hline$M-5$ & 500 & 288 & 6 & $\begin{array}{l}\text { USGS / } \\
\text { PCWS }\end{array}$ & $\begin{array}{l}(\mathrm{K}, \mathrm{DS}, \mathrm{C}, \\
\left.\mathrm{SO}_{4}, \mathrm{~S}\right), \mathrm{m}\end{array}$ & $\begin{array}{l}320 \\
350 \\
410 \\
490\end{array}$ & $\begin{array}{l}\text { None } \\
\text { None } \\
\text { None } \\
\text { None }\end{array}$ & $\begin{array}{l}\text { None } \\
\text { None } \\
\text { None } \\
\text { None }\end{array}$ & Regulatory \\
\hline $3 A$ & 1,100 & 670 & 8 & $\begin{array}{l}\text { USGS / } \\
\text { PCWS }\end{array}$ & $\begin{array}{l}(\mathrm{K}, \mathrm{DS}, \mathrm{C}, \\
\mathrm{SO}, \mathrm{S}), \mathrm{sa}\end{array}$ & $\begin{array}{r}700 \\
1,000 \\
1,100\end{array}$ & $\begin{array}{l}\text { None } \\
\text { None } \\
\text { None }\end{array}$ & $\begin{array}{l}\text { None } \\
\text { None } \\
\text { None }\end{array}$ & Data \\
\hline $\mathrm{N}-1$ deep & 1,200 & 653 & 8 & $\begin{array}{l}\text { USGS / } \\
\text { PCWS }\end{array}$ & $\begin{array}{l}(\mathrm{K}, \mathrm{DS}, \mathrm{C}, \\
\left.\mathrm{SO}_{4}, \mathrm{~S}\right), \mathrm{sa}\end{array}$ & $\begin{array}{r}700 \\
1,100 \\
1,180\end{array}$ & $\begin{array}{l}\text { None } \\
\text { None } \\
\text { None }\end{array}$ & $\begin{array}{l}\text { None } \\
\text { None } \\
\text { None }\end{array}$ & Data \\
\hline$M-2$ & 538 & 507 & 6 & $\begin{array}{l}\text { USGS / } \\
\text { PCWS }\end{array}$ & $\begin{array}{l}(\mathrm{K}, \mathrm{DS}, \mathrm{C}, \\
\left.\mathrm{SO}_{4}, \mathrm{~S}\right), \mathrm{sa}\end{array}$ & $\begin{array}{l}510 \\
535\end{array}$ & $\begin{array}{l}\text { None } \\
\text { None }\end{array}$ & $\begin{array}{l}\text { None } \\
\text { None }\end{array}$ & Regulatory \\
\hline
\end{tabular}


Table 4.--Chloride concentrations in water from selected observation wells

\begin{tabular}{|c|c|c|c|c|c|c|}
\hline \multirow{2}{*}{ We11 } & \multirow{2}{*}{$\begin{array}{c}\begin{array}{c}\text { Regulatory } \\
\text { limits }\end{array} \\
\begin{array}{c}\text { Chloride } \\
(\mathrm{mg} / \mathrm{L})\end{array}\end{array}$} & \multirow{2}{*}{$\begin{array}{l}\text { Date } \\
\text { sampling } \\
\text { began }\end{array}$} & \multicolumn{2}{|c|}{$\begin{array}{l}\text { Maximums since } \\
\text { sampling began }\end{array}$} & \multicolumn{2}{|c|}{$\begin{array}{c}\text { Chloride } \\
\text { concentration } \\
(\mathrm{mg} / \mathrm{L})\end{array}$} \\
\hline & & & $\begin{array}{c}\text { Chloride } \\
(\mathrm{mg} / \mathrm{L})\end{array}$ & $\begin{array}{l}\text { Date of } \\
\text { maximum }\end{array}$ & $9 / 77$ & $9 / 78$ \\
\hline $\begin{array}{l}\text { Brooker Creek } \\
\text { shallow }\end{array}$ & 1,200 & $3 / 72$ & 1,000 & $6 / 76$ & 780 & 830 \\
\hline Brooker Creek deep & 1,500 & $8 / 73$ & 1,400 & $1 / 74$ & 1,300 & 1,300 \\
\hline D\&S Ranch & 100 & $1 / 61$ & 38 & $2 / 62$ & 9 & 8 \\
\hline $\mathrm{M}-2,510 \mathrm{ft}$ & $-\infty$ & $1 / 75$ & 1,900 & $9 / 76$ & 1,450 & 1,480 \\
\hline $\mathrm{M}-2,535 \mathrm{ft}$ & --- & $1 / 75$ & 2,270 & $6 / 77$ & 2,120 & 1,910 \\
\hline Bryan Dairy & 50 & $1 / 61$ & 11 & $4 / 77$ & 9 & 8 \\
\hline Casey Ranch & 250 & $1 / 61$ & 185 & $11 / 77$ & 154 & 115 \\
\hline North Lake Tarpon & 10,500 & $9 / 71$ & 13,000 & $3 / 76$ & 12,000 & 12,000 \\
\hline S.W. deep, $560 \mathrm{ft}$ & 150 & $10 / 73$ & 150 & $7 / 77$ & 69 & 62 \\
\hline S.W. deep, $620 \mathrm{ft}$ & 550 & $10 / 73$ & 550 & $1 / 77$ & 215 & 157 \\
\hline S.W. deep, $730 \mathrm{ft}$ & 6,000 & $10 / 73$ & 8,250 & $1 / 77$ & 6,000 & 3,650 \\
\hline $3 \mathrm{~A}, 700 \mathrm{ft}$ & -- & $9 / 73$ & 215 & $12 / 76$ & 188 & 172 \\
\hline $3 \mathrm{~A}, 1,000 \mathrm{ft}$ & --- & $9 / 73$ & 275 & $2 / 76$ & 198 & 205 \\
\hline $3 \mathrm{~A}, 1,100 \mathrm{ft}$ & -- & $9 / 73$ & 800 & $4 / 77$ & 200 & 259 \\
\hline $\mathrm{N}-1$ deep, $700 \mathrm{ft}$ & --- & $3 / 69$ & 95 & $7 / 76$ & 44 & 44 \\
\hline $\mathrm{N}-1$ deep, $1,100 \mathrm{ft}$ & --- & $3 / 69$ & 12,000 & $12 / 76$ & 51 & 59 \\
\hline $\mathrm{N}-1$ deep, $1,800 \mathrm{ft}$ & --- & $3 / 69$ & 14,740 & $5 / 73$ & 300 & 59 \\
\hline N.W. shallow, $320 \mathrm{ft}$ & --- & $2 / 76$ & 25 & $7 / 77$ & 21 & 20 \\
\hline S.W. sha1low, $350 \mathrm{ft}$ & --- & $10 / 73$ & 15 & $8 / 76$ & 11 & 12 \\
\hline
\end{tabular}


suggest that it is tapping a zone that is always below the freshwater-saltwater interface. Water from the lowest level of the S.W. deep well had a lower maximum chloride concentration and varied significantly in chloride concentration during 1977. Therefore, it appears that the lowest level in the S.W. deep we11 taps the zone through which the freshwater-saltwater interface fluctuates (Joyner and Gerhart, 1980).

Figure 14 shows variations of chloride concentrations at specific depths for September 1978 along a section from Tarpon Lake to N-1 deep we11 in the Eldridge-Wilde well field (fig. 1). Measurements show that chloride concentrations greater than $250 \mathrm{mg} / \mathrm{L}$ in the Eldridge-Wilde well field are about 700 feet deeper than the average 350-foot depth of the production wells in the field. The deepest production well in the Eldridge-Wilde well field is 805 feet, about 300 feet above the leve1 where concentrations exceed $250 \mathrm{mg} / \mathrm{L}$.

WATER USE

The Cypress Creek well field (located about 15 miles northeast of the Eldridge-Wilde well field) began pumping in April 1976 enabling the Pinellas County Water System to meet its growing water-supply needs without excessively pumping the E]dridge-Wilde and East Lake Road well fields. Figure 15 shows the monthly pumpage from Cypress Creek, East Lake Road, and Eldridge-Wilde well fields for 1974-78. The maximum monthly pumpage from the Eldridge-Wilde well field was 1,245 Mgal in March 1976. The maximum monthly pumpage from East Lake Road well field was 151 Mgal in April 1976. Cypress Creek well field produced a monthly maximum of $945 \mathrm{Mgal}$ in May 1978, of which $573 \mathrm{Mgal}$ went into the Pinellas County Water System. The maximum aggregate monthly pumpage--the total water pumped from the three well fields for the Pinellas County Water System-was 1,722 Mgal in May 1978. This was a 3.5 percent increase or 56 Mgal more than May 1977.

\section{MODIFICATIONS IN OBSERVATION-WELL NETWORK, 1978}

The following additions or modifications in the monitoring network were made in and adjacent to the Eldridge-Wilde and East Lake Road well fields in 1978 .

1. Began monthly water-level measurements on well $\mathrm{M}-5$ at the golf course.

2. Began monthly sampling of Tarpon Road deep well for specific conductance and chloride concentrations.

3. Discontinued E-103 water-1eve1 measurements and water-quality sampling due to well caving in.

4. Discontinued N.W. deep well water-quality sampling due to caving in and began monthly water-level measurements. 


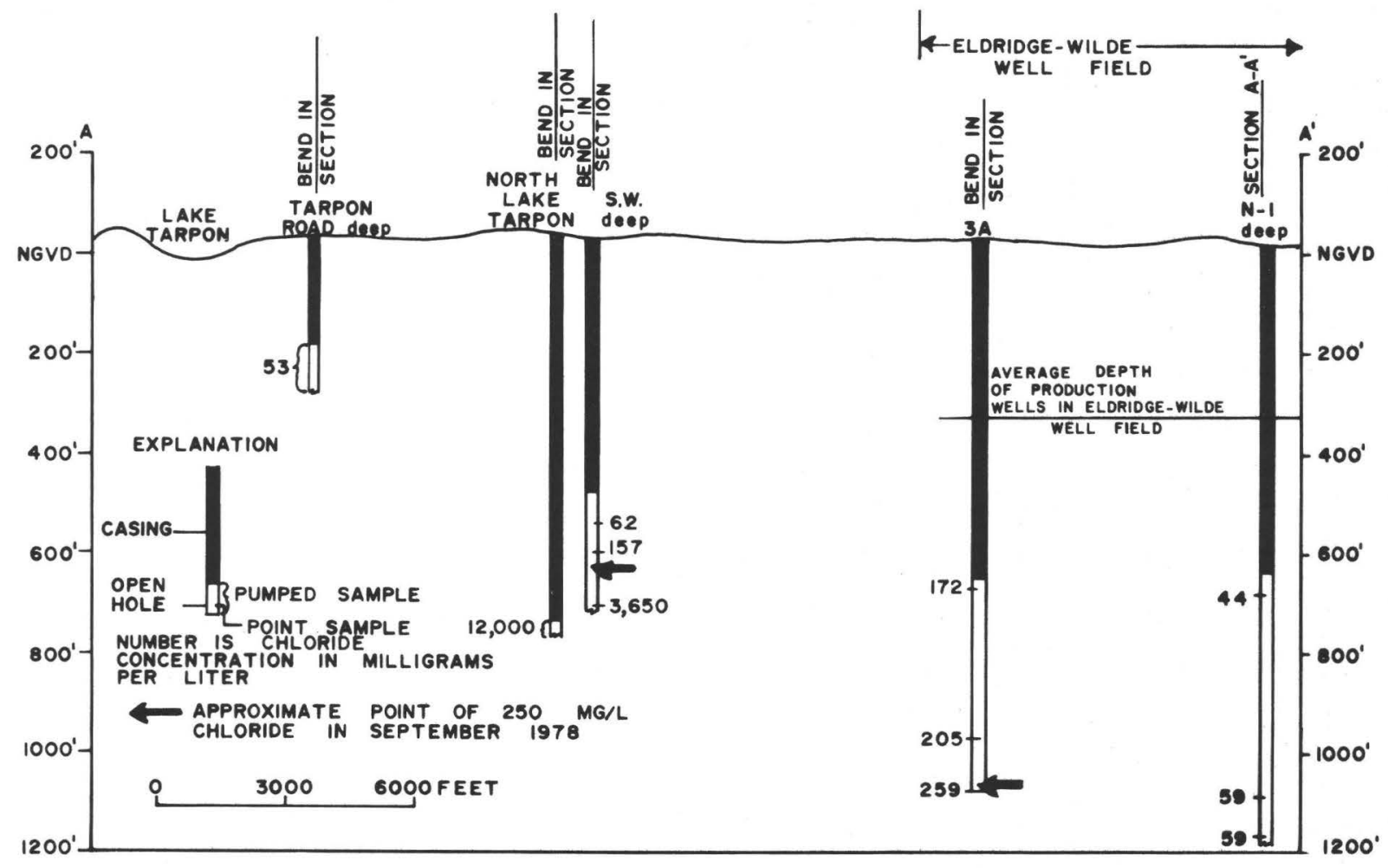

Figure 14.--Section showing chloride concentrations at specific depths, September 1978.

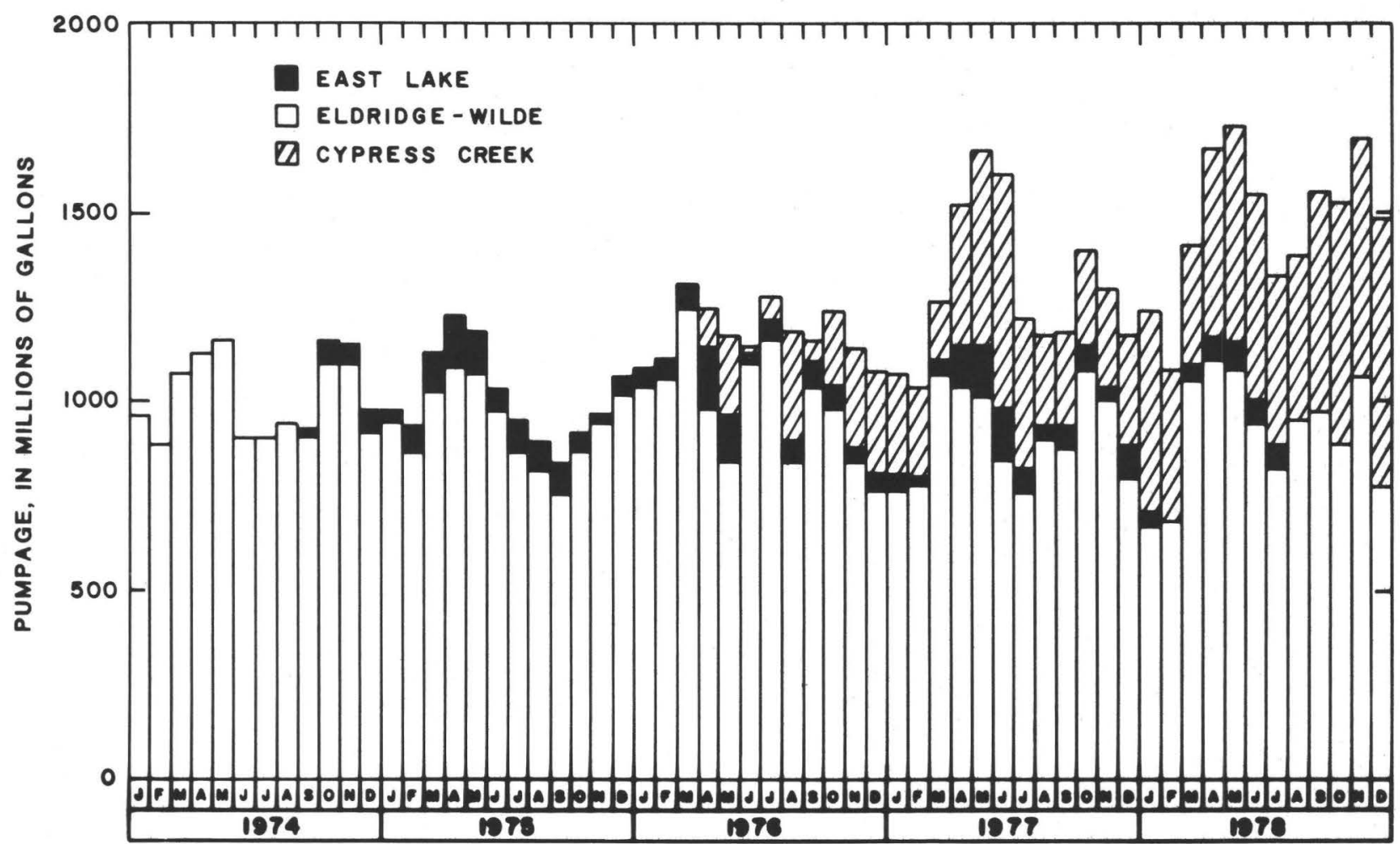

Figure 15.--Monthly supply to Pinellas County Water System from Eldridge-Wilde, East Lake Road, and Cypress Creek well fields, 1974-78. 
CONCLUSIONS

The Eldridge-Wilde and East Lake Road well fields are being extensively monitored for water levels and water quality in both the surficial and the Floridan aquifers. The Floridan aquifer is monitored by'means of observation wells open to the production zone and wells that penetrate the freshwater-saltwater interface.

A normal rainfall of 52 inches occurred in the Eldridge-Wilde well field in 1978 resulting in water table and potentiometric surface levels that were about average. The water table and potentiometric surface were 2 feet higher in May 1978 than in May 1977.

Chloride concentrations generally increase during the low precipitation months of April and May. This increase in chloride concentrations coincides with the period of sparse rainfall, increased pumpage, and lower levels of the water table and the potentiometric surface.

The hydrologic stress on the Eldridge-Wilde and East Lake Road well fields has received some relief since the Cypress Creek well field began operation in April 1976. The highest monthly pumpage from the Cypress Creek well field was about 945 Mgal in May 1978, of which 573 Mgal was distributed to the Pinellas County Water System, relieving some of the demand from the Eldridge-Wilde and East Lake Road well fields.

\section{SELECTED REFERENCES}

Black, Crow and Eidsness, Inc., 1976, Hydrologic monitor program for the Pinellas County Water System: Black, Crow and Eidsness, Inc., Project No. 272-74-02.

Brown, D. W., 1958, Interim report on the changes in the chloride content of ground water in Pinellas County, Florida: Florida Geological Survey Information Circular 16, $11 \mathrm{p}$.

Cherry, R. N., 1963, Chloride content of ground water in Pinellas County, Florida: Florida Geological Survey Map Series 20.

Heath, R. C., and Smith, P. C., 1964, Ground-water resources of Pinellas County, Florida: Florida Geological Survey Report of Investigation 12, 139 p.

Joyner, B. F., and Gerhart, J. M., 1980, Hydrologic monitoring program in Eldridge-Wilde and East Lake Road well-field areas, Pinellas and Hillsborough Counties, Florida, 1977 water year: U.S. Geological Survey OpenFile Report 80-345.

Ryder, P. D., and Mills, L. R., 1977, Water table in the surficial aquifer and potentiometric surface of the Floridan aquifer in selected well fields, west-centra1 Florida, May 1977: U.S. Geological Survey Open-File Report 77-552, map.

1978, Water table in the surficial aquifer and potentiometric surface of the Floridan aquifer in selected well fields, west-central Florida, September 1977: U.S. Geological Survey Open-File Report 78-9, map. 
Wolansky, R. M., Mills, L. R., and Woodham, W. M., 1978a, Water table in the surficial aquifer and potentiometric surface of the Floridan aquifer in selected well fields, west-central Florida, May 1978: U.S. Geological Survey Open-File Report 78-939.

$1978 \mathrm{~b}$, Water table in the surficial aquifer and potentiometric surface of the Floridan aquifer in selected well fields, west-central Florida, September 1978: U.S. Geological Survey Open-File Report 78-1045. 
UNITED STATES DEPARTMENT OF THE INTERIOR GEOLOGICAL SURVEY

325 John Knox Rd--Suite F240

Tallahassee, Florida 32303
POSTAGE AND FEES PAID

U.S. DEPARTMENT OF THE INTERIOR

INT. 413 